\title{
- José de Alencar e a crítica literária
}

\section{Gilda Vilela Brandão}

Professora Associada 3 e doutora em Literatura

Brasileira na linha de pesquisa Literatura e

História, lotada na Faculdade de Letras da

Universidade Federal de Alagoas (Ufal), onde

ensina Língua e Literatura Francesas nos cursos

de graduação e Expressão Literária no Programa

de Pós-Graduação em Letras e Linguística.

Resumo: $\mathrm{O}$ trabalho comenta alguns juízos críticos acerca da obra de José de Alencar (1829-1877); destaca o julgamento do romancista sobre sua criação, seu método de interpretação que pretendeu aplicar à sua obra romanesca e sobre sua defesa contra ataques de inverossimilhança artística. Entre a crítica da época e reinterpretações mais atuais de sua obra romanesca, 0 artigo situa Alencar no quadro histórico da cultura brasileira, de que é representativo.

Palavras-chave: José de Alencar; crítica literária; polêmica Alencar-Nabuco; romantismo brasileiro
Résumé: Le travail commente quelques jugements critiques portant sur l'oeuvre de José de Alencar (1829-1877); il met en évidence le jugement que le romancier lui-même porte sur sa création, sur sa méthode interprétative qu'il a voulu appliquer à son oeuvre et sur son requisitoire contre des attaques censées invraisemblables. Entre la critique faite à l'époque et des interprétations récentes de son oeuvre romanesque, l'article situe Alencar dans le cadre historique de la culture brésilienne, dont il est le représentant.

Mots-clés: José de Alencar ; critique littéraire ; polémique Alencar-Nabuco ; romantisme brésilien 

Não sabia, eu então que, em meu país, essa luz, que dizem glória, e de longe se nos afigura radiante e esplêndida, não é senão o baço lampejo de um fogo de palha. (José de Alencar, apud DONATO, s. d., p. 21)

Mágoa, pessimismo e desânimo é o que revelam as palavras acima, ditas por um homem arredio, franzino e, dizem, até ranzinza, morto de tuberculose aos 48 anos. Talvez, ao escrevê-las, José de Alencar autor-síntese de nosso romantismo e página obrigatória de nossa história literária - mirasse uma glória duradoura como a que obteve Victor Hugo (18021885), aquele que tendo almejado "ser Chateaubriand ou nada" ("être Chateaubriand ou rien"), pregou a mistura de gêneros, tumultuando a cena literária de seu tempo e deixando para trás seu circunspecto modelo. O cotejo Alencar-Hugo pode surpreender, mas não é inócuo. Ao mencionar o triste (e cômico) destino de $O s$ contrabandistas, ${ }^{1}$ livro que deveria marcar seu début literário, Alencar confessa que "sua feitura havia de ser consoante à inexperiência de um moço de 18 anos, que nem possuía o gênio precoce de Victor Hugo, nem tinha outra educação literária, senão essa superficial e imperfeita, bebida em leituras a esmo" (ALENCAR, 1990, p. 52; o grifo é meu). Postas à parte contingências históricas e agruras políticas - Hugo, exilado por Louis Napoléon III (1808-1873); Alencar, menosprezado por D. Pedro II $(1825-1891)^{2}$ —, une-os, além da visão idealizante da realidade, típica do romantismo, uma constante insubordinação a normas de comportamento estéticas, tradicionais e consagradas. Sem, talvez, o alto potencial subversivo de Hugo, Alencar, com seu modo ranzinza de ser, irritou, em diversas ocasiões, os intelectuais e políticos de seu tempo. Sua atitude combativa manifesta-se por ocasião da publicação do poema "Confederação dos tamoios" (1856), de Domingos José Gonçalves de Magalhães (1811-1882), o que lhe valeria impropérios de toda ordem:
1 "Meus queridos manuscritos, o mais precioso tesouro para mim, eu os trancara na cômoda; como, porém, tomassem o lugar da roupa, os tinham, sem que eu soubesse, arrumado na estante. Daí, um desalmado hóspede, todas as noites, quando queria pitar, arrancava uma folha, que torcia a modo de pavio e acendia na vela" (ALENCAR, 1990, p. 51).

2 Segundo Lídia Besouchet, no romance à clef $\mathrm{de}$ Alencar [A guerra dos mascates], o imperador está retratado no personagem de Sebastião de Castro Caldas. Cf. BESOUCHET, Lídia. Exílio e morte do imperador. Rio de Janeiro: Nova Fronteira, 1975, p. 191. 
[...] Num golpe que deveria chamar sobre si a atenção geral fustigou impiedosamente o poeta Domingos Gonçalves de Magalhães, que trazia da Europa, impresso às custas do imperador, o poema "A confederação dos tamoios". Com tudo isso, logrou a certa altura ter mobilizada contra a sua pessoa e a sua obra a mais formidável de quantas coalisões [sic] de talento, ressentimento, malquerença e também de inveja já se formaram no país. Mont'Alverne, Tobias Barreto, Joaquim Nabuco, Franklin Távora, Feliciano de Castilho investiram-no no terreno individual, enquanto Zacarias de Góis e Vasconcelos e Silveira Martins insistiam em bloqueá-lo no legislativo. Dentro do seu próprio partido político Paranhos, Cotegipe e outros o arrastavam sem pena para o calvário político. (DONATO, s.d. p. 20).

Na morosidade de nosso Romantismo, "geralmente tão acomodado e sem bulha" (CANDIDO, 1964, p. 356), a polêmica veio a lume em Questôes do dia,

uma revista panfleto que se editou aqui no Rio, sob a orientação e coordenação de JOSÉ FELICIANO DECASTILHO, que tomou pseudônimo de LÚCIO QUINTO CINCINATO. Vários nela colaboraram, escolhendo cada qual um falso-nome. Creio que só se publicaram quarenta números, que foram enfeixados em dois volumes: Questões do dia - observações políticas e literárias, escritas por vários e coordenadas por LÚCIO QUINTO CINCINATO, 2 tomos. Rio [1871]. Quase tudo que se contém nesses dois tomos é contra Alencar. É uma campanha de desmoralização e de descrédito, organizada e levada a efeito com técnica e minúcia, um ataque sistemático e constante ao político, ao jurista, ao dramaturgo, ao romancista, ao escritor. Sobressaem nessa mesquinha atividade José Feliciano de Castilho, Cincinato, e FRANKLIN TÁVORA, Semprônio, apostados em reduzir os méritos literários de Alencar (CHAVES DE MELLO, 1957, p. 20). 
As réplicas de Alencar - contidas, segundo Chaves de Mello (1957, p. 25), no pós-escrito à segunda edição de Diva; no prefácio apenso à segunda edição de Sonhos d'ouro, intitulado "Bênção paterna"; no pós-escrito de Iracema, segunda edição, datada de 1870; e em um ensaio inacabado, publicado em 1919, na revista América Latina - revelam, além de sua verve crítica, sua concepção de literatura, posta em prática em $O$ guarani (1857), o primeiro romance a dar mostras de sua adesão narrativa ao mundo primitivo. Para Gladstone Chaves de Mello, enquanto Távora/Semprônio "ateve-se, quase que só à parte literária propriamente dita, pouco tratando de 'erros' de linguagem", os ataques de Castilho/Cincinato recaem sobre infrações às regras gramaticais: o escritor português censura a concordância ("Fui um dos que corri"); o uso do verbo "partilhar" no sentido de "compartir", e o emprego do adjetivo "faceiro" com o sentido de "gentil, mimoso, engraçado, airoso, galante"; a colocação de pronomes ("que lançou-se"); a criação de neologismos ( "tinha a boquinha a mais gentil") e outras "impropriedades vocabulares" usadas por Alencar com a intenção clara de "abrasileirar a língua portuguesa”(CHAVES DE MELLO,1957, p. 20-23). As respostas de Alencar, incisivas, acenam para a mudança de hábitos linguísticos. E, quando afirma "convictamente que a língua não poderia ficar estacionada e que era de mister procurar ajustá-la, como instrumento dócil, à manifestação dos novos gostos" (ib., p. 26), há ecos remotos de Victor Hugo.

Por comodidade, recorro agora, resumidamente, a Antonio Candido (1964) e a Gilberto Freyre (1977) para deslindar algumas invectivas de Alencar contra o poema de Gonçalves de Magalhães: ausência da "luz tropical", falha na composição das mulheres "a ponto de poderem figurar ao mesmo tempo num poema brasileiro e num romance árabe" (FREYRE, 1977, p. XXIV); ausência de rasgos sublimes na descrição da natureza, pobreza de estilo na narração de cenas heroicas, falha na caracterização dos índios, "dando-lhes uma dimensão inferior, apresentandoos sem virilidade nem grandeza" e ausência de "uma 
heroína feminina comovente, um tipo feminino poetizado que perfumasse os versos e contrastasse os lances de epopeia (CANDIDO, 1964, p. 357).

Tendo, como argumento maior, "a inferioridade da realização de Magalhães ante a magnitude do objeto" (ib., loc.cit.), Ig (nom de plume adotado por Alencar nessas Cartas) desenvolve ideias que, mesmo não sendo substancialmente diferentes dos velhos anseios nativistas a que esteve ligada tradicionalmente nossa literatura, trazem, em um gênero emergente - o romance um timbre próprio, para o qual, aliás, François-René, visconde de Chateaubriand (1768-1848), não demonstrou nenhum interesse, numa evidência clara de que literatura e condições históricas particulares não acontecem desvinculadamente: trata-se da conhecida simbiose entre a representação da natureza e a problemática da identidade, de que trataremos mais adiante - instância simbólica legitimadora de uma literatura nacional. Contudo, esse gosto estético passaria por sérios reveses, como mostra este argumento levantado por Franklin Távora (1842-1888) nas mencionadas Cartas. Para Távora (1872, p. 249),

Há um grande erro de forma na obra do Sr. José de Alencar: essa linguagem sempre figurada, que ele põe a cada instante na boca dos bárbaros, como se fossem todos poetas. Está enganado; o uso que faziam de tropos era determinado tão somente pela necessidade quando tinham de exprimir as ideias abstratas, para as quais lhes faltavam termos. Fora disso, o seu modo de exprimir-se havia de ser grosseiro, rústico e simples, porque a mais não lhe permitia saber o estado de embrutecimento intelectual e moral, em que seu espírito jazia imerso.

O autor de $O$ cabeleira (1876) condena Alencar por ter criado um código linguístico incompatível com a natureza rude do aborígene, e isso naturalmente tem tudo que ver com o princípio aristotélico da verossimilhança. Para não alongar em demasiado a discussão, ocorre-me 
esta apreciação, curiosa, pirandelliana: "Os absurdos da vida não precisam ser verossímeis porque são verdadeiros. Ao contrário dos absurdos da arte que, para se afigurarem verdadeiros, precisam ser verossímeis. E, então, sendo verossímeis, não precisam mais ser verdadeiros ${ }^{3 "}$. O problema é que a categoria da verossimilhança assumiu tantas formas ao longo do tempo e vem levantando tantos dilemas que podemos considerar os "absurdos" de Alencar tão inverossímeis quanto os de Defoe (Robinson Crusoe) ou de More ( $A$ utopia). O que é plausível para o leitor é, sem dúvida mais ainda, para o menino-leitor dos "romances marítimos de Walter Scott e Cooper" (ALENCAR, 1990, p. 50) e de romances folhetins, como Saint-Clair das ilhas, lidos nos serões familiares. Levese ainda em consideração que, para a epistemologia idealista - base do romantismo - , o conhecimento tem por origem o próprio indivíduo; e sabemos que Alencar incorpora essa cosmovisão romântica da arte. Desprendido da contingência histórica, o romancista pôde dispensála em parte, dando-lhe a conformação estética desejada, segundo sua invenção pessoal. Não é sem razão que no horizonte estético de Alencar, afirma Bosi (1993, p. 177), "o índio entra em comunhão com o colonizador". Se "essa conciliação, dada como espontânea por Alencar, viola abertamente a história da ocupação portuguesa no primeiro século [...], toca o inverossímil no caso de Peri” (ib., p. 179), entendo que isso se deveu ao triunfo do mito, pois, para Bosi, o mito constitui uma dimensão interna essencial à obra alencariana: "o mito não quer o teste da verificação nem se vale daquelas provas testemunhais que fornecem passaporte idôneo ao discurso historiográfico" (ib., loc.cit.). Então, em suas turras com a história real, Alencar foi salvo pelo mito.

É exatamente por esse flanco mítico-arcaico que Joaquim Nabuco (1849-1905), fazendo eco a Távora, ataca Alencar em uma longa polêmica, iniciada em 18 de setembro de $1875^{4}$, logo após a estreia do drama $O$ jesuíta, e que se prolongou de 3 de outubro a 21 de novembro de 1875 . Duas fortes personalidades se enfrentam: de
3 Não tendo, infelizmente, a referência completa, só posso informar que o trecho foi extraído da série publicada na revista Manchete, provavelmente na década de 80 do século passado, intitulada "As obras-primas que poucos leram". A obraprima estudada é $O$ falecido Matias Pascal, de Pirandello (18671936). Josué Montello é o autor desse ensaio.

${ }^{4}$ Coube a Afrânio Coutinho a iniciativa de publicar o debate em livro, sob o título A polêmica AlencarNabuco (1978). No jornal O globo, Joaquim Nabuco escreve sob a rubrica "Aos domingos" e José de Alencar sob o título “Às Quintas”. 
5 Apelido dado por Zacarias de Góis a Alencar, devido à sua baixa estatura e compleição franzina (DONATO, s. d. , p. 56).

${ }^{6}$ A discussão entre nacionalismocosmopolitismo será colocada apenas nos limites levantados pelos contendedores.

\section{Em Minha formação,} Joaquim Nabuco arrepende-se de seu tom aguerrido "Fui colaborador literário do Globo e travei com José de Alencar uma polêmica, em que receio retratado com a presunção e a injustiça da mocidade o grande escritor - (digo, receio, porque não tornei a ler aqueles folhetins e não me recordo até onde foi a minha crítica, se ela ofendeu o que há profundo, nacional, em Alencar: o seu brasileirismo)" (NABUCO, 1900, p. 87). um lado, o Fanadinho ${ }^{5}$, com seu nacionalismo saudável, de dedicação aos símbolos pátrios; de outro, Quincas, o Belo, cidadão do mundo, o Apolo de gesso, como o chamara Alencar (COUTINHO, 1978, p. 53), para quem qualquer figuração que relembrasse a velha colônia era extremamente enjoativa, de mau gosto, desprezível, coisa do passado. Como diz Afranio Coutinho em sua "Introdução" (ib., p.7): "Ao ocidentalismo de Nabuco opunha-se o nacionalismo de Alencar; ao universalismo do primeiro, a tendência nacionalizante do segundo. Colocados dentro dessa perspectiva, estamos aptos a compreender a polêmica entre os dois grandes espíritos". O ponto alto da discussão é, pois, o debate entre nacionalismo e cosmopolitismo ${ }^{6}$ literário, com direito a uma segunda área de atrito: a de plágio. Vejamos como, dentro de um clima mútuo de ironia e animosidade, ${ }^{7}$ argumentos e contra-argumentos se desenvolvem. Conforme estudos críticos têm infatigavelmente assinalado, havia, para Alencar, a necessidade de erigir lendas e fatos históricos à condição privilegiada da estrutura literária, como, aliás, fizeram os românticos e postulara o controverso Johan Herder (1774-1803), fundador do nacionalismo étnico, xenófobo, segundo acusam uns, e defensor de sua cultura frente à ameaça de culturas poderosas, creem outros. É nessa direção arquivista que, parafraseando a própria criação, Alencar, em resposta datada de 7 de outubro, declara: "[Iracema e Ubirajara] são lendas inspiradas por nossas tradições americanas, que também formam a pátria brasileira, pois encerram a história do solo que habitamos" (ib. p. 59). Narrações fantasiosas, de cunho popular, não agradavam de modo algum a Nabuco (ib., p. 83-84), que, desdenhando esse passado rústico, levanta semelhanças, para ele insuspeitas, entre a obra alencariana e a de Chateaubriand - assunto incendiário:

De todas as obras do Sr. José de Alencar a mais popular é ainda $O$ guarani. [...] No momento em que o Sr. J. de Alencar pensou em escrever o seu romance, diversas influências pesavam-lhe sobre o espírito. [...] Que futuro, que relação com 
o país, que razão de ser, que direito chamar-se brasileira tinha essa falsa literatura tupi, é que eu discutirei, não hoje, mas a propósito de Iracema e Ubirajara.

Todos sabem que no princípio do século, Chateaubriand fundou uma poesia nova, e que essa poesia saiu das florestas americanas. Atala $e$ Os natchez, que encerravam-na, impressionaram o Sr. J. de Alencar [...]. A impressão foi por tal modo forte que, ainda hoje, os índios do escritor brasileiro pensam, amam e falam como se fossem amigos de René. Por outro lado, Cooper deu ao Sr. J. de Alencar o cenário do romance [...]. Foi depois de ler Atala que o Sr. J. de Alencar sentiu sua imaginação voar para as grandes florestas.

Para Alencar, a valorização do índio não era um chavão artístico importado. Naturalmente, a dependência de nossa literatura às convenções de fonte europeia foi o gargalo pelo qual sua criação teve de passar, porém sem nenhum prejuízo para sua qualité maîtresse, o vigor narrativo, ou, melhor ainda, seu "exaltado senso visual [...] quase sempre diretamente descritivo [com o qual construía] por vezes certas visões sintéticas de um luminoso impressionismo" (CANDIDO, 1964, p. 230). Embora seguro da importância de seu trabalho, o escritor cearense revela fragilidade, sobretudo quando os comentários de seu adversário batem na tecla da imitação, trilha escorregadia. Acossado, usa, como contra-argumento, ora o fator externo da boa recepção de sua obra por parte do público: "Plagiário? Já foi repetido à saciedade; e isso não impede o leitor brasileiro de achar em meus livros um sabor nativo que ao gosto parisiense do crítico há de excitar náusea" (COUTINHO, 1978, p. 61). Ora o fator cronológico não atentava, nesse caso, para as enormes diferenças formais existentes entre ambos, numa demonstração evidente de um modelo de reflexão crítica (não propriamente uma crítica no sentido técnico da palavra) produzida à época, por meio do qual, geralmente, eram traçadas comparações 
${ }^{8} \mathrm{O}$ embate Alencar-

Nabuco não é

considerado aqui

uma crítica literária

propriamente dita.

Fique claro também

que a colocação feita

não pretende, de modo

algum, diminuir o valor

da crítica realizada

no período. Sobre a

crítica acadêmica, ver:

MERQUIOR, José

Guilherme. La crítica

brasileña desde 1922. In:

PIZARRO, Ana (Org).

América Latina: palavra,

literatura e cultura. São

Paulo: Unicamp, 1995,

p. 675-696.

9 Em 11 de novembro,

Alencar, "o autor

agredido", como ele

próprio se denomina, manifesta cansaço: "Esta

discussão já perdeu

todo o interesse; é

uma questão cansada.

Os sintomas do tédio

público revelam-se de

modo sensível. Notam-

se a cada instante, e de

toda parte, os bocejos

de opinião, e mal se

disfarçam já uns assomos

de impaciência.[...].

Mais uma semana, e o

folhetinista domingueiro

ficará reduzido a

dois leitores, ele e eu

: ele, por devoção;

eu, por obrigação"

(COUTINHO, 1978, p.

165). temáticas entre obras situadas em contextos históricos os mais diversos possíveis. ${ }^{8}$ Usando a prerrogativa temporal, Alencar afirma (ib., p. 93-94) que a literatura brasileira descobrira e inventara o índio antes mesmo de o escritor francês tê-lo encampado:

É erro afirmar que Chateaubriand fundou uma poesia saída das florestas americanas. O primeiro poeta que inspirou-se na musa americana foi, se não me engano, Ercilla, na sua Araucânia, escrita de 1569 a 1590 . É certo que falta a esse poema o colorido, como bem notou Sismondi; mas a descrição dos araucanos e seus combates apartamse da escola clássica. Temos ainda Marmontel, o autor dos Incas, onde já se encontram belas descrições, e no Brasil colonial, Santa Rita Durão, o autor do Caramuru, e José Basílio da Gama, com seu Uraguay, todos do século XVIII. Quando Chateaubriand publicou Atala em princípio deste século, a poesia americana já estava criada, até no Brasil; ele não fez mais do que dar-lhe o realce de seu talento.

Seu discurso argumental, bem fundamentado na medida do possível, erudito - fruto de suas leituras a esmo - revela um homem amargurado, solitário, cansado $^{9}$ (sua morte ocorreria dois anos mais tarde) pela tentativa de persuadir o autor de Minha formação (1900) da autenticidade estética de sua literatura e do significado de sua obra. Isso o leva a explicar e justificar detalhes (risíveis, até) levantados por $\mathrm{Nabuco}^{10}$, acusando-o, reiteradamente, de excesso de parisianismo ${ }^{11}$, de ter os pés fincados no Faubourg Saint-Germain, fora, portanto, de sua cultura de origem; por conseguinte, de estar incapacitado de emitir juízos críticos sobre sua obra. É o que se lê nos fragmentos abaixo, extraídos das páginas publicadas respectivamente em 7 e 28 de outubro:

O aparecimento de Ubirajara e Senhora incomodara ao folhetinista, e porventura o movera a descer dos salões, onde paira a sua elegância 
parisiense, ao rodapé de um jornal brasileiro, em risco de confundir-se com a plebe da imprensa (COUTINHO, 1978, p. 55).

O folhetinista, pois, não tem ideia nem convicção alguma sobre qualquer assunto, a não ser o da sua pessoa, e da preocupação, que se trai a cada instante, de cortejar o estrangeiro. Vive aqui no Rio de Janeiro; faz a este solo a honra de pisá-lo; mas é cidadão do Faubourg Saint-Germain. ( ib., p. 121).

Tinha razão Alencar, pois, de fato, em Minha formação, uma "autobiografia coletiva", como assim sintetizou Gilberto Freyre, no prefácio à edição de 1981, Nabuco percebe estar dividido entre dois mundos. Em "Atração do mundo", com seu estilo elegante, cadenciado, fino e sedutor, confessa:

Nós, brasileiros - o mesmo pode-se dizer de outros povos americanos -, pertencemos à América pelo sedimento novo, flutuante, do nosso espírito, e à Europa, por suas camadas estratificadas. [...]. A nossa imaginação não pode deixar de ser europeia, isto é, de ser humana; ela não para na Primeira Missa no Brasil, para continuar daí recompondo as tradições dos selvagens que guarneciam as nossas praias no momento da descoberta; segue pelas civilizações todas da humanidade, como a dos europeus, com quem temos o mesmo fundo comum de língua, religião, arte, direito e poesia, os mesmos séculos de civilização acumulada, e, portanto, desde que haja um raio de cultura, a mesma imaginação histórica. [...] O sentimento em nós é brasileiro, a imaginação europeia. (NABUCO, 1900, p. 40-41)

Com todas suas variantes, o debate, avis rara nos dias atuais, inscreve-se em um momento extremamente curioso na vida literária do país, quando novas propostas literárias já estavam em curso. Em 1875, Alencar estava no final de sua longa carreira, iniciada em 1856, com
10 "No Guarani descreve-se a onça no momento do assalto 'com o corpo direito e os dentes prestes a cortar a jugular do índio'. O meu atilado crítico leu, pensou e concluiu que 'o tigre devia ter certo conhecimento de anatomia.." (COUTINHO, 1978, p. 97).

${ }^{11}$ A acusação de francesismo acha-se mais bem desenvolvida no meu artigo "Imagens fin de siècle", aceito para publicação na revista Letras, da Universidade Federal de Santa Maria. 
Cinco minutos, que, "para o primeiro grande crítico e biógrafo a se ocupar da vida e da obra de José de Alencar [Araripe Júnior], era simplesmente uma miniatura, com uns misteriozinhos de fácil desenlace" (MAGALHÃES JÚNIOR, 1977, p. 76), e, para Candido (1964, p. 223), um romance onde "tudo corre como se o dinheiro fosse um dado implícito, as personagens agindo independentemente dele". Em termos cronológicos, a polêmica AlencarNabuco seria o canto do cisne do romantismo, premido pela literatura verista, sugere Coutinho (1978, p. 8): "ao findar de uma era histórica e artística, o Romantismo, [a polêmica] é um exemplo flagrante desse dualismo de concepções históricas, sociais e literárias". Poucas décadas antes, no entanto, o alumbramento pelo passado heroico constituíra um elemento de superação da "consciência de inferioridade à metrópole", com a natureza servindo permanentemente de elo para a expressão de um sentimento nacional:

Quanto durou esta consciência de inferioridade à metrópole, é difícil determinar com precisão. [...]. Seguiu-se então a consciência mais ou menos clara da igualdade à metrópole. Os brasileiros inspiraram-se nas glórias portuguesas [...]. Era preciso alguma coisa que pudesse elevá-los à altura em que pairavam os portugueses. Para este fim prestou-se a natureza [...]. É preciso ler Rocha Pita para ver o sentimento em toda a sua força. (ABREU, 1976, p. 120).

Tudo indica que, nos trópicos, a relação entre literatura e paisagem trouxe, subjacente, um ideologema a mais para o tópico literário do locus amoenus, estudado por Curtius: o lugar ameno e paradisíaco passa a ser também um lugar único, um lugar que não existe em nenhuma outra parte. Como a identidade, em termos amplos, é entendida como algo singular, que não se encontra em qualquer outra parte, opera-se uma fusão, ou melhor, uma transfusão de sentidos: o lugar ameno, físico, concreto (o espaço representado) converge para um 
espaço abstrato, mental (a pátria). Antonio Candido já havia anotado que Santa Rita Durão, em seu poema épico Caramuru, não seguira o molde recomendado na epopeia, pois a celebração da natureza, como lugar edênico, não se limitava mais a um único espaço, como é comum no estilo épico, mas o transcendia: "No Caramuru, todavia, há uma generalização desta prática; o poeta amplia o lugar de maravilhas até fazê-lo coincidir com todo o país e, deste modo, descaracterizar a sua função" (CANDIDO, 1961, p. 54). O país inteiro é moldado como um lugar perfeito. Em Alencar e Gonçalves Dias, nacionalismo e paisagem condicionam-se mutuamente, e esse esforço, que esteve na origem e sustentou suas obras, é o traço que os diferencia do romantismo francês e distingue, em essência, Alencar de Chateaubriand. Pois, examinando bem, escassas são as semelhanças estético-discursivas entre ambos, cuja origem estudos acadêmicos recentes remetem invariavelmente ao mito romântico do bon sauvage, elaborado por JeanJacques Rousseau (1712-1778), que o tratou no Discurso sobre as ciências e as artes (1750) e no Discurso sobre a origem e os fundamentos da desigualdade entre os homens (1755). É possível que a comparação não tivesse o endosso do filósofo iluminista, nem de seus intérpretes, uma vez que estaria faltando o núcleo duro de sua tese, segundo a qual o Estado moderno, em nome do progresso, destruiu a liberdade, a igualdade e a bondade primitivas, conforme expressa em seus escritos filosóficos, nos quais manifesta a ruptura com seu século. Salvo a comunhão com a natureza, com a poesia do mundo selvático, Alencar teria pouco a ver com essa complexa moldura ideológica, assim como se distancia da mundivivência do criador de Atala, ${ }^{12}$ cujos heróis e heroínas condensam toda a gama de atitudes que definem o mal do século: melancolia atroz, ideia de morte, isolamento, religiosidade, sentimentalismo derramado. Contudo, é ainda pelo veio da imitação que, em seu artigo “Alencar”, Agripino Grieco (1931), ainda que afastasse semelhanças intencionais, convoca uma miscelânea de influências, no meio das quais figura Chateaubriand:
12 Inicialmente, um episódio dos Natchez, a história de Atala (1826) aparece na edição inglesa de Le génie du christianisme. A fábula conta a história de um francês, René, que, em 1725, se refugia na tribo indígena dos natchez. Um velho cego, Chactas, leva-o a contrair matrimônio com uma índia, Céluta. Em uma noite, René pede a Chactas que lhe conte suas aventuras. $\mathrm{O}$ velho faz o longo relato de seu idílio com a meia-índia, Atala, desde o primeiro encontro até a noite em que, em plena selva, Atala se suicida, envenenandose. 
13 O interessante é que, lendo esse ensaio de Grieco, pude comprovar o seu método analítico, para o qual chamou atenção João Luiz Lafetá: (2000): o portrait, o famoso retrato de Sainte-Beuve. No ensaio, Grieco faz um rápido apanhado da obra, levanta um aspecto parabiográfico (Alencar escreve $O$ guarani "num quarto estreito e sem elementos de consulta") e um traço de temperamento (“Alencar insulou-se em si mesmo desde criança, fez da solidão a sua pátria moral"). Sobre a metodologia de Grieco, ver LAFETÁ, 2000, p.54.
E, afinal, veio o Guarani, em que o Brasil, três séculos mudo, encontrou a sua voz, começou a falar... Aí falaram as águas, as árvores e as criaturas do Brasil, e, como nos mitos celtas ou nas histórias de Andersen, talvez as coisas falassem muito melhor que os homens [...]. E a Iracema? Aí está um poema sem rimas. É bem, como a classificaram, a "pastoral tupy", embora outros, muito exigentes, exigentes demais, aí enxergassem apenas portugueses pintados a urucum. Aí estão, abrasileirados, um pouco de Chateaubriand, da Bíblia, dos cantos homéricos e das baladas gaélicas (GRIECO, 1931, p.172-173). ${ }^{13}$

E aqui chamo de modo muito particular atenção para o lugar que José de Alencar ocupou na crítica de sua época e nos decênios imediatos que lhe sucederam, uma modalidade de crítica via de regra norteada pelo crivo da ideia de nação ("Aí falaram as águas, as árvores e as criaturas do Brasil"), isto é, de um modo de ser que necessariamente espelhasse o nacional. De fato, o discurso estético do Alencar "heroico, altissonante" (CANDIDO, 1964 , p. 220) sempre buscou aquela integração, ideal à primeira vista, um tanto quanto distinto do "Alencar das mocinhas - criador de mulheres cândidas e de moços impecavelmente bons, que dançam aos olhos do leitor uma branda quadrilha" (ib. p. 222) e de "um terceiro Alencar, menos patente que esses dois, mas constituindo não raro a força de um e outro. É o Alencar que se poderia chamar dos adultos, formado por uma série de elementos pouco heroicos e pouco elegantes" (ib., loc.cit.). Próximo ao terceiro Alencar está o Alencar teatrólogo, dois arrojados, de boa têmpera, ante os quais o primeiro Alencar ainda se inibia. São os que assinam As asas de um anjo (1860) e Lucíola (1862), cujo domínio de referência é a prostituição feminina. Mas é a peça a causadora de um novo litígio, desta feita com a censura. Estreando com sucesso no teatro em 28 de outubro de 1857, com $O$ Rio de Janeiro (Verso e Reverso), "metade revista, metade comédia” (MAGALHÃES JÚNIOR, 1977, p. 106), Alencar 
escreve no Diário do Rio de Janeiro uma carta aberta a Francisco Otaviano, intitulada $A$ comédia brasileira, "que bem poderia ter tido como título Como e porque sou dramaturgo" (ib., p. 104). Diz ele (apud MAGALHÃES JÚNIOR, ib., p. 105):

A primeira ideia que tive de escrever para o teatro foi-me inspirada por um fato bem pequeno e, aliás, bem comesinho [sic] na cena brasileira. Estava no Ginásio e representava-se uma pequena farsa, que não primava pela moralidade e pela decência da linguagem; entretanto o público aplaudia e as senhoras riam-se, porque o riso é contagioso; porque há certas ocasiões que ele nos vem aos lábios, embora o espírito e o pudor se revoltem contra a causa que o provoca. (o grifo é meu).

Sem dúvida, o enunciado grifado anuncia o esquema da peça As asas de um anjo, pela associação destes dois sentimentos tão complexos e variáveis segundo as épocas e as culturas: a permissividade e o pudor. Julgava Alencar poder equilibrá-los, ao pôr em cena a história da costureira Carolina, que, deixando para trás o terno Luís e a casa de seus pais para se amasiar com homens ricos (Ribeiro e Pinheiro), retorna à casa, doente e arrependida. A desejada lição moralizadora dissolveu-se; no entanto, devido ao fato de a peça conter duas cenas de "incesto involuntário", levando os censores do Conservatório Dramático Brasileiro e o chefe de polícia, Isidoro Monteiro Borges, a proibi-la em sua terceira récita, a peça voltaria à cena onze anos depois, quando Alencar exercia o posto de Ministro da Justiça. Além disso, paira mais uma vez sobre Alencar a suspeita de influências tributárias da literatura francesa: a Carolina de As asas de um anjo "é uma dama sem camélias e com prole", dizia-se (ib., p. 129). Alencar reage tomando como pretexto para o escândalo a proximidade entre a representação teatral e a vida real:

Dizia Alencar que quem assistia à Dama das camélias ou às Mulheres de mármore, esta de Théodore Barrière, estreada em 1853, em 
Paris, achava que tanto a Margarida Gautier, da primeira peça, quanto a Marcô [sic] da segunda, eram apenas "duas moças um tanto loureiras" [...]. Mas, com As asas de um anjo era diferente: e o espectador encontrava a realidade diante de seus olhos, espantando-se de ver na cena teatral "o que vê todos os dias à luz do sol, no meio da rua, nos passeios e espetáculos" (ib., p. 132).

Claro está que tanto a escrita quanto a fala teatral dão a ilusão de que aquilo que se lê e se ouve é verdadeiro. Para Alencar, no entanto, o leitor, num caso, e o espectador no outro, não têm a mesma reação, um diante da página escrita, outro diante da voz. A partir dessa conjectura, fica latente, no pensamento do romancista, a ideia de enfrentar a censura por meio da enunciação silenciosa do romance, pois, conforme afirma Santos (2003, p.203), “o romance, destinado a ser lido, permite a abordagem de temas delicados, com mais sutileza que a representação dramática, detalhe que não escapou a Alencar". E De Marco (1986, p. 152) ratifica: "Através dessas precauções do narrador, Alencar constrói uma resposta altiva e sisuda à gritaria dos censores e do público que, em 1858, tirara de cena As asas de um anjo". A abertura de Lucíola é, ao mesmo tempo, um recado metalinguístico aos seus censores e, ao mesmo tempo, um diálogo com seu público, sutilmente representado na pessoa da "velha senhora". Vale a pena ler os primeiros parágrafos em que o autor compara o ofício de narrar à roupa feminina: a ideia deve ser trabalhada e refletida; do mesmo modo que a vestimenta, é preciso que não seja tão forte a ponto de desnudar os encantos da mulher e nem tão fraca a ponto de escondê-los:

Asenhora estranhou, naúltima vezque estivemos juntos, a minha excessiva indulgência pelas criaturas infelizes, que escandalizam a sociedade [...]. Quis responder-lhe imediatamente, tanto é o apreço em que tenho o tato sutil e esquisito da mulher superior para julgar de uma questão de 
sentimento [...]. Receei também que a palavra viva, rápida e impressionável não pudesse, como a pena calma e refletida, perscrutar os mistérios que desejava desvendar-lhe, sem romper os fios da tênue gaza com que a fina educação envolve certas idéias, como envolve a moda em rendas e tecidos diáfanos os mais sedutores encantos da mulher.

Além de o romance Lucíola ter sido visto como uma cópia de $A$ dama das camélias, como se Lúcia/Lucíola e Marguerite Gauthier fossem idênticas no tempo e na história - relações, aliás, que De Marco (1986) averigua cuidadosamente - , o romancista, vítima de abordagens críticas dicotomizadas, é acusado de fazer uma literatura que não encontrava respaldo em nossos códigos históricoculturais. Em "Bênção paterna" (1977, p. 167), Alencar retruca afirmando que encontrou na sociedade afrancesada fluminense a estrutura para seus romances:

Dessa luta entre o espírito conterrâneo e a invasão estrangeira, são reflexos Lucíola, Diva, A pata da gazela, e tu, livrinho [Sonhos d'Ouro]. Tachar estes livros de confeição estrangeira é, relevem os críticos, não conhecer a fisionomia da sociedade fluminense, que aí está a faceirar-se pelas salas e ruas com atavios parisienses, falando a algemia universal, que é a língua do progresso, jargão eriçado de termos franceses, ingleses, italianos e agora também alemães.

O criador de vinte e um romances, dos quais, disse Candido (1964, p. 219), "nenhum é péssimo", sempre suscitou, como vimos, o interesse da crítica. Em um enfoque inovador, Roberto Schwarz (2000, p. 39), ao considerar os processos de transformação pelos quais o romance brasileiro teve de passar em sua formação, releva os defeitos do romance alencariano. Para o crítico, o elo com a tradição passa por uma linha que vai de Alencar a Guimarães Rosa, passando por Mário de Andrade. O que é 
extremamente salutar, haja vista que os modernistas de 22 minimizaram os românticos e seus excessos nativistas.

A sua obra [de Alencar] é uma das minas da literatura brasileira, até hoje, e embora não pareça, tem continuidades com o Modernismo. De Iracema, alguma coisa veio até Macunaíma, as andanças que entrelaçam as aventuras, o corpo geográfico do país, a toponímia índia e a História branca; alguma coisa do Grande-Sertão já existia em Til, no ritmo das façanhas de Jão Fera [...]. É preciso reconhecer que a sua obra nunca é propriamente bem sucedida, e que tem sem um quê de descalibrado e, bem pesada a palavra, de bobagem. É interessante notar, contudo, que esses pontos fracos são, justamente, fortes noutras perspectivas.

$\mathrm{O}$ escritor que perguntava a Taunay (apud DONATO, s. d., p. 18) "Você acha que passarei à posteridade? Não nutro essa segurança [...]" foi brindado, em seu enterro, pelo seu contemporâneo mais novo, Machado de Assis (1839-1908), com um poema de estrutura parnasiana (ib., p. 26),

Naquele eterno azul, onde Coema [sic],

Onde Lindoia, sem temor dos anos,

Erguem os olhos plácidos e ufanos,

Também os ergue a límpida Iracema.

Elas foram, nas águas do poema,

Cantadas pela voz de americanos,

Mostrar às gentes de outros oceanos

Joias do nosso rútilo diadema.

E, quando a magna voz inda afinavas

Foge-nos, como se a chamar sentiras

A voz da glória pura que esperavas.

O cantor do Uruguai [sic] e o dos Timbiras

Esperavam por ti, tu lhe [sic] faltavas

Para o concerto das eternas liras .

Descanse em paz. 


\section{Referências}

ABREU, José Capistrano de. Ensaios e estudos. 2. ed. 3ạ série. Rio de Janeiro: Civilização Brasileira; Brasília: INL, 1976.

(Crítica e história).

ALENCAR, José de. Bênção paterna. In: ALENCAR, José de. Sonhos d'ouro. 7. ed. Rio de Janeiro: INL, 1977. p. 162-168.

ALENCAR, José de. Como e porque sou romancista. [Adaptação ortográfica de Carlos de Augusto Pereira]. Campinas: Pontes, 1990.

BOSI, Alfredo. Um mito sacrificial: o indianismo de Alencar. In: BOSI, Alfredo. Dialética da colonização São Paulo: Companhia das Letras, 1993. p. 176-193.

CANDIDO, Antonio. Os três Alencares. In: CANDIDO, Antonio. Formação da literatura brasileira (momentos decisivos). 2. ed. rev. São Paulo: Martins Editora, 1964. v. 2. p. 218-232.

CANDIDO, Antonio. Estrutura e função do Caramuru. In: Revista de Letras. São Paulo: Faculdade de Filosofia, Letras e Artes, 1961. v. 2. p. 47-66.

CHAVES DE MELLO, Gladstone. Introdução. In: ALENCAR, José de. Senhora (perfil de mulher). 4. ed. Rio de Janeiro: José Olympio, 1957. p. 15-88.

COUTINHO, Afrânio (Org.). A polêmica Alencar-Nabuco. Rio de Janeiro: Tempo Brasileiro; Brasília: Editora da Universidade de Brasília, 1978.

DE MARCO, Valéria. O império da cortesã - Lucíola, um perfil de Alencar. São Paulo: Martins Fontes, 1986.

DONATO, Hernâni. José de Alencar. São Paulo: Melhoramentos, s.d. (Grandes vultos das letras).

FREYRE, Gilberto. José de Alencar, renovador das letras e crítico social. In: ALENCAR, José de. Til; O sertanejo. Rio de Janeiro: José Olympio, 1977. p. X-XXVI. 
GRIECO, Agripino. Alencar. In: GRIECO, Agripino. Vivos e mortos. São Paulo: Schmidt, 1931.

LAFETÁ, João Luiz. Retórica e alienação (Agripino Grieco). In: LAFETÁ, João Luiz. 1930: a crítica e o modernismo. São Paulo: Duas Cidades, 2000. p. 39-74.

MAGALHÃES JÚNIOR, R. José de Alencar e sua época. 2. ed. (corrigida e aumentada). Rio de Janeiro: Civilização Brasileira; Brasília: INL, 1977.

MERQUIOR, José Guilherme. La crítica brasileña desde 1922. In: América Latina - palavra, literatura e cultura, São Paulo: Unicamp, 1995. p. 677-696.

NABUCO, Joaquim. Minha formação. 10. ed. Brasília: Editora da Universidade de Brasília, 1981.

NABUCO, Joaquim. Minha formação. Rio de Janeiro: Garnier Livreiro-Editor, 1900.

SANTOS, Wellington de Santos. Narrativa e pudor. In: MARCHEZAN, Luiz Gonzaga; TELLAROLI, Sylvia. Faces do narrador. Araraquara: Unesp; São Paulo: Cultura Acadêmica, 2003. p. 201-213.

SCHWARZ, Roberto. A importação do romance e suas contradições em Alencar. In: Ao vencedor, as batatas: forma literária e processo social nos inícios do romance brasileiro. 5 . ed. São Paulo: Duas Cidades, 2000.

TÁVORA, João Franklin de Oliveira. Cartas a Cincinatoestudos críticos de Semprônio. 2. ed. Pernambuco: J.W. de Medeiro Livreiro-editor, 1872. 